\title{
Bimbingan Teknis Pembelajaran Daring SD Muhammadiyah Muara Jawa Tahun Pembelajaran 2020/2021
}

\author{
Nur Agus Salim \\ *Universitas Widya Gama Mahakam Samarinda \\ *nuragussalim@uwgm.ac.id
}

\begin{abstract}
During the Covid-19 pandemic, schools continue to carry out online learning. The purpose of the implementation of this service is to provide understanding to schools and teachers in the implementation of online learning and to guide teachers in online learning practices. The method of implementing PPM activities is carried out in the form of training including Lectures. The lecture method is used to deliver material about online learning, and the types of applications that can be used in the implementation of online learning. The practical method is used to independently practice online learning applications in schools. The next method is to ask questions, share, and practice mentoring.
\end{abstract}

Keywords: Technical guidance, Online Learning

\begin{abstract}
Abstrak
Pada masa Pandemi Covid-19 sekolah tetap melaksanakan pembelajaran secara daring. Tujuan dari pelaksanaan pengabdian ini adalah memberikan pemahaman kepada sekolah dan guru dalam pelaksanaan pembelajaran daring serta membimbing guru dalam praktek pembelajaran daring. Metode kegiatan pelaksanaan PPM dilakukan dalam bentuk pelatihan meliputi Ceramah Metode ceramah digunakan untuk menyampaikan materi mengenai pembelajaran daring, dan jenis-jenis aplikasi yang dapat digunakan dalam pelaksanaan pembelajaran daring. Metode praktik digunakan untuk mempraktekkan aplikasi pembelajaran daring secara mandiri di sekolah. Metode selanjutnya adalah dengan Tanya Jawab, sharing, dan pendampingan praktik.
\end{abstract}

Kata kunci: Bimtek, Pembelajaran Daring

\section{PENDAHULUAN}

Salah satu cara untuk memutus mata rantai penyebaran COVID-19 adalah dengan melakukan pembatasan interaksi masyarakat yang diterapkan dengan istilah physical distancing. Namun, kebijakan physical distancing tersebut dapat menghambat laju pertumbuhan dalam berbagai bidang kehidupan, baik bidang ekonomi, sosial dan tentu saja pendidikan. Keputusan pemerintah untuk meliburkan para peserta didik, memindahkan proses belajar mengajar di sekolah menjadi di rumah. Oleh karena itu sekolah dihimbau untuk melaksanakan pembelajaran secara daring untuk tahun pelajaran 2020/2021.

Sistem pembelajaran daring merupakan sistem pembelajaran tanpa tatap muka secara langsung antara guru dan siswa tetapi dilakukan melalui online yang menggunakan jaringan internet. Hal ini sesuai dengan himbauan Menteri Pendidikan dan Kebudayaan Indonesia melalui Surat Edaran Nomor 4 Tahun 2020 tentang Pelaksanaan Kebijaksanaan Pendidikan dalam masa Darurat Penyebaran Corona Virus Disease ( COVID-19). Namun pemerintah belum menyiapkan platform pembelajaran daring bagi sekolah sehingga sekolah memanfaatkan platform pembelajaran tersedia secara gratis. Banyak platform pembelajaran daring gratis selama masa pandemi ini salah satunya adalah platform pembelajaran daring yang disediakan oleh google.

Pemerintah tidak membatasi sekolah dalam melaksanakan pembelajaran daring agar sekolah dapat menyesuaikan dengan kondisi masing-masing. Sistem pembelajaran dapat dilaksanakan melalui perangkat personal computer (PC), Laptop atau handphone yang 
terhubung dengan koneksi jaringan internet. Guru dapat melakukan pembelajaran bersama diwaktu yang sama menggunakan grup di media sosial seperti WhatsApp, telegram, Aplikasi Zoom Cloud Meeting ataupun media lainnya. Dengan demikian, guru dapat memastikan siswa mengikuti pembelajaran dalam waktu yang bersamaan, meskipun di tempat yang berbeda.

Namun seiring dengan penerapannya banyak kendala yang dihadapi oleh sekolah dan guru baik dari aspek fasilitas, sumber daya manusia dan biaya yang dibutuhkan dalam pelaksanaan pembelajaran daring. Oleh karena itu penting dilaksanakan pendampingan pelaksanaan pembelajaran daring kepada sekolah agar pembelajaran dapat terlaksana secara efektif dan efesien.

\section{METODE PELAKSANAAN}

\section{Tempat dan Waktu.}

Kegiatan ini dilakukan di SD Muhammadiyah yang beralamat di Kelurahan Muara Jawa Kecamatan Muara Jawa Kabupaten Kutai Kartanegara Kalimantan Timur pada bulan Oktober s/d Nopember tahun 2020.

\section{Metode Kegiatan}

Metode kegiatan pelaksanaan PPM dilakukan dalam bentuk pelatihan meliputi:

1. Ceramah Metode ceramah digunakan untuk menyampaikan materi mengenai pembelajaran daring, dan jenis-jenis aplikasi yang dapat digunakan dalam pelaksanaan pembelajaran daring.

2. Praktik. Metode praktik digunakan untuk mempraktekkan aplikasi pembelajaran daring secara mandiri di sekolah. Kegiatan praktik dilakukan untuk memberikan pengalaman dan pengetahuan kepada guru dalam melaksanakan pembelajaran daring karena dalam kegiatan akan diadakan simulasi kelas pembelajaran.

3. Tanya Jawab, sharing, dan pendampingan praktik

Metode Tanya jawab dan sharingdilakukan untuk menggali permasalahan yang berhubungan dengan materi ceramah dan kendala saat melakukan praktik. Sedangkan pendampingan praktik dilakukan agar tahapan praktik dapat berjalan sesuai rencana.

\section{Peserta dan Narasumber}

Peserta pelatihan Bimbingan Teknis (BIMTEK) pembelajaran daring melibatkan instruktur dan mahasiswa PPG.

Peserta kegiatan berasal dari Guru SD Muhamadiyah Kecamatan Muara Jawa

Narasumber BIMTEK adalah tenaga professional yang dipandang memiliki kepakaran pada bidang IT, dari kalangan akademisi yang memiliki pengalaman luas pada bidangnya dan memiliki sertifikasi di bidang TIK.

Nama Pemateri IT : Dr. Nur Agus Salim, M.Pd

Pekerjaan : Dosen Universitas Widya Gama Mahakam Samarinda.

\section{Tempat dan Waktu Pelaksanaan}

Pelaksanaan kegiatan Bimtek Pembelajaran daring dilaksanakan pada tanggal 19 Oktober 2020 bertempat di Aula SD Muhammadiyah Muara Jawa.

\section{HASIL DAN PEMBAHASAN}

Google class room bisa diakses dengan mudah bagi pengguna layanan google seperti gmail dan google suite. Pada panduan ini, kami akan memberikan panduan terkait layanan 
google suite untuk google classroom. Untuk mengaksesnya, bisa mengikuti panduan berikut ini :

1. Akses https://classroom.google.com/ . Klik Buka Classroom

2 . Masukkan email google suite serta passwordnya kemudian klik login.

Ada beberapa yang akan kami jelaskan dari tampilan awal diatas. Jika diperhatikan, maka akan ada 2 opsi yang disediakan yakni join class dan juga create class. Apa perbedaannya? Berikut keterangannya :

- Join class adalah opsi yang biasa digunakan untuk murid input code class yang sudah dibuat oleh guru.

- Create class umumnya digunakan untuk guru untuk membuat class tertentu yang nantinya akan digunakan sebagai ruang pembelajaran online. Create class ini akan menghasilkan kode class yang bisa digunakan murid untuk join menggunakan menu join class.

Untuk penggunakan layanan google suite, maka sebagai email administrator ada beberapa setting yang bisa disesuaikan sesuai kebutuhan pengguna. Untuk editing settingnya, bisa dilakukan dari admin.google.com dan login menggunakan email serta password administratornya. Silakan lihat gambar dibawah untuk step by stepnya :

- Login ke admin.google.com

- Cari menu Apps > Additional Google services > Cari Google classroom

Cari Menu App Klik Menu Additional Google servicesCari Google Classroom dan klik pada iconnya Tampilan Setting untuk Classroom

Kemudian akan muncul beberapa setting administrator yang mana bisa disesuaikan sesuai kebutuhan. Kami akan kupas satu persatu setting tersebut agar lebih paham ;

\section{Teacher Permissions}

\section{Teacher Permissions}

Opsi ini digunakan untuk pengaturan akses akun email mana saja yang diizinkan menjadi guru. Ada 3 opsi yang disediakan;

- Anyone in this domain : seluruh akun email google suite di domain tersebut diizinkan untuk menjadi guru dan dizinkan untuk create class.

- All Pending and verified teachers : seluruh akun email yang belum diijinkan maupun sudah bisa create class dan menjadi guru.

- Verified teacher only : hanya akun email yang di ijinkan saja yang bisa untuk create class

\section{Guardian Access}

Guardian Access

Maksud dari setting guardian access adalah setting yang mengijinkan siapa saja yang boleh

mengundang wali untuk mendapatkan rekapan hasil pembelajaran siswa. Guardian access

juga mengijinkan wali menerima email berisi progress hasil pembelajaran yang

putra/putrinya lakukan di google classroom. Jika ingin default, bisa diabaikan setting

tersebut.

\section{About Class Membership}

Setting "About Class Membership" digunakan untuk mengatur alamat email dari mana saja yang bisa bergabung dengan class yang dibuat oleh akun google suite Anda dan mengatur akun google suite anda bisa join ke class mana saja.

Who can join classes in your domain (Siapa saja yang boleh mengikuti kelas domain Anda)

- Users in your domain only : hanya akun email domain anda yang boleh bergabung ke class

- Users in whitelisted domains : hanya akun email dari domain yang di whitelist yang bisa bergabung

- Any GApps User : semua akun layanan google suite

- Any User : semua akun google suite dan email google lainnya (gmail)

Which classes can useres in your domain join ( Kelas mana saja yang bisa diikuti oleh akun domain Anda)

- Classes in your domain only : kelas yang dibuat oleh akun domain Anda 
- Classes in whitelisted domains : Kelas yang dibuat oleh domain yang sudah di whitelist

- Any G Suite Class : semua kelas dari akun google suite

\section{Whitelist Domain}

Whitelist domain

Opsi ini digunakan untuk mengatur domain domain apa saja yang akan dijadikan list whitelist.

\section{Classroom API}

Sebagai administrator G Suite, Anda dapat memilih apakah pengguna di domain Anda dapat memberikan akses ke data Kelas mereka ke aplikasi lain melalui OAuth. Untuk informasi lebih lanjut, baca ikhtisar API Classroom atau lihat semua detail teknis API Classroom di developers.google.com/classroom.

Setelah melakukan setting sebagai administrator pada admin console, selanjutnya Anda bisa memulai class pada google classroom. Mari kita lihat satu persatu fitur yang ada di google classroom.

\section{PEMBUATAN KELAS DAN INVITE ANGGOTA}

Anda bisa melakukan create class dan melakukan pengisian data sesuai kelas yang akan Anda buat. Seperti yang sudah dijelaskan diatas, terdapat fitur join class yang mana diminta untuk menginputkan kode class. Kode class bisa didapatkan di halaman ruang guru seperti ini :

Selain siwa yang menginputkan kode classnya sendiri, guru juga bisa untuk invite guru lain atau siswa lain di dalamnya menggunakan fitur "People". Sebagai admin/guru Anda hanya cukup klik (+) dan isikan alamat email yang akan diikutkan ke dalam kelasnya.

Stream Classwork People Grades

diperhatikan, bahwa akun yang bisa diinvite hanya akun yang sudah disetting di pengaturan administrator di admin.google.com seperti penjelasan pada gambar "About Class Membership".

Setelah seluruh anggota siap, tahap selanjutnya adalah memulai pembelajaran.

\section{MEMBUAT PENGUMUMAN, PENUGASAN DAN UJIAN ONLINE DENGAN CLASSROOM}

\section{SHARED SOMETHING WITH YOUR CLASS}

Pembuatan pengumuman atau semacam "woro-woro" kelas akan dimulai pukul berapa bisa dilakukan dari google classroom lho. Pada fitur ini semacam fitur untuk update status pada 
kelas yang dibuat. Caranya mudah cukup klik menu "shared something with your class" dan isikan pengumuman apa yang akan diposting disana.

Apabila ingin menambahkan attachment, bisa di klik add dan tambahkan attachment file yang dibutuhkan kemudian klik post.

\section{2 . CLASSWORK}

Pada fitur ini, Anda bisa membuat assigment, quiz maupun shared material pembelajaran. Mari kita bahas satu persatu :

\subsection{ASSIGMENT}

Cara membuat assigment cukup dengan klik menu create $>$ pilih assigment. Pada dasarnya sama dengan klik "shared something" yang ada di beranda, namun pada menu classwork ini lebih

spesifik.

Di dalamnya, terdapat pengaturan point nilai untuk assignment yang diberkan hingga setting report yang akan di hasilkan. Anda juga bisa tambahkan attachment seperti link google drive, file bahkan hingga youtube. Jika dirasa sudah siap publish, silakan bisa di klik "Assign". Assigment

Untuk membatasi waktu kerja siswa dalam mengerjakan tugasnya Anda bisa melakukan setting pembatasan waktu pada kolom "Due".

Selesai dipublish, tampilan pada siswa akan seperti ini :

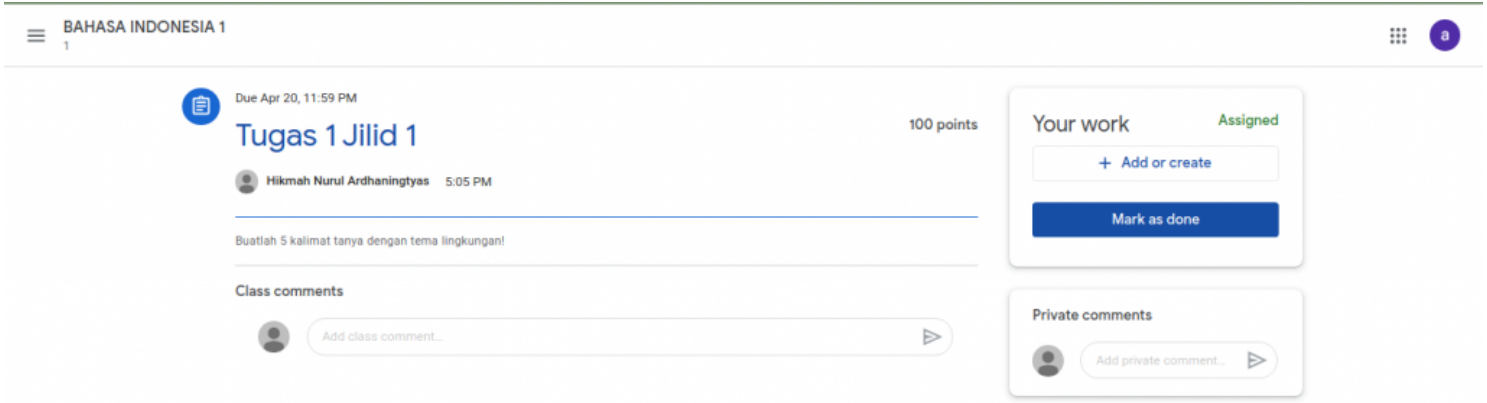

Siswa bisa mengirimkan tugasnya, dengan cara klik + Add or create file baik bentuk google docs, excell atau file lain. Setelah selesai di uploadkan, siswa cukup klik "Turn In" untuk mensubmit hasil pekerjaannya.

\section{2 . 2 . QUIZ ASSIGMENT}

\section{2 . 2 . 1 . MEMBUAT HALAMAN IDENTITAS SISWA}

Fitur ini bisa membuat ulangan harian atau ujian online yang akan dibuat. Silakan bisa mengikuti panduan ini :

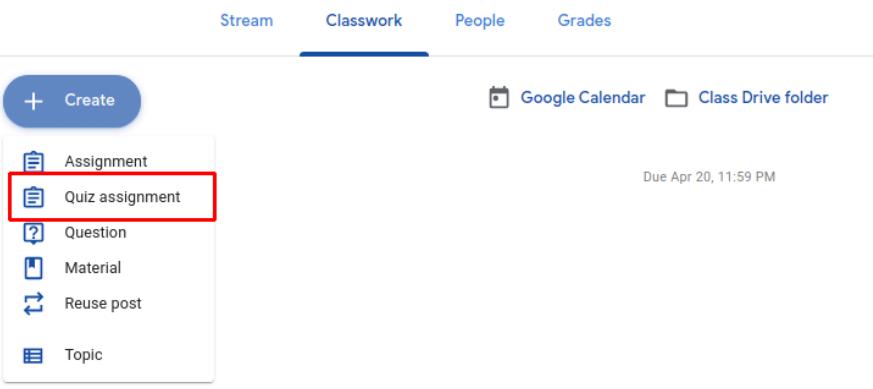

Nantinya, akan otomatis create sebuah google form dengan nama default "Blank Quiz" . Form itu digunakan untuk membuat soal ujian. Silakan klik Blank Quiz 


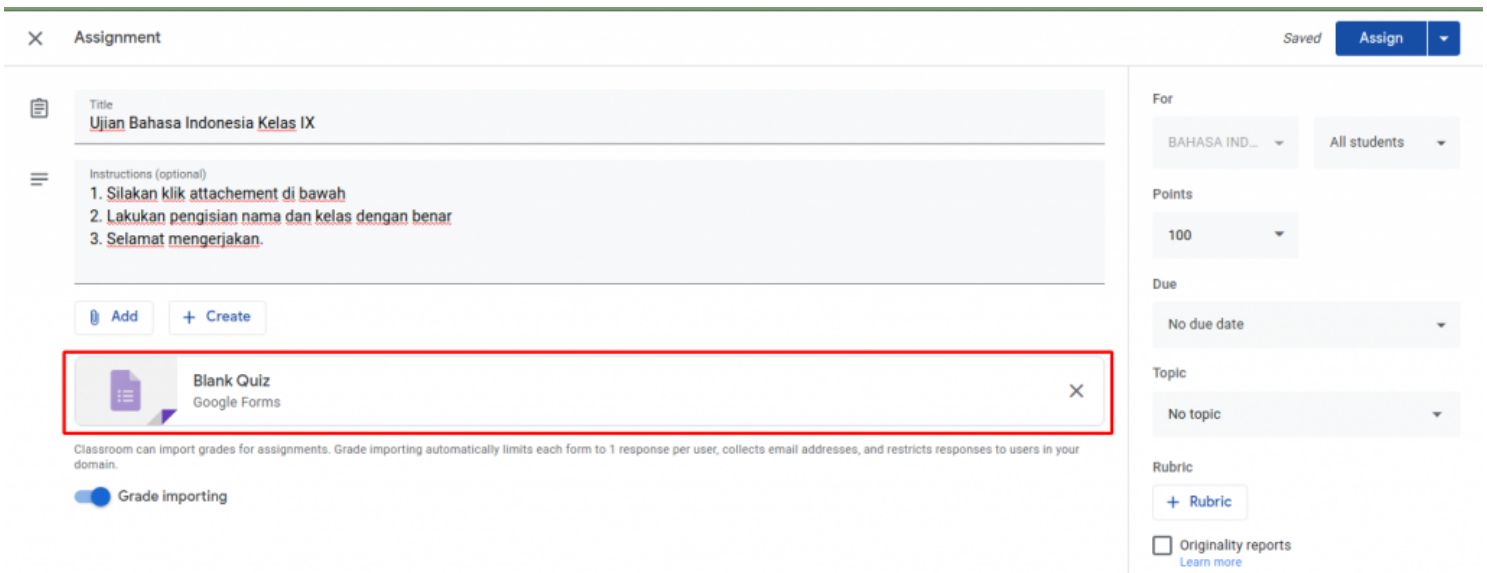

Selanjutnya, bisa disamakan dengan panduan ini dalam hal layout membuat soalnya atau bisa improvisasi sesuai dengan keinginan layout ujian yang akan dibuat.

\section{2 . 2 . 2. MEMBUAT TOKEN UJIAN}

Token ujian digunakan sebagai kode akses masuk ke ujian yang mana untuk validasi bahwa memang siswa yang diberikan kode akses saja yang bisa akses soal yang Anda buat. Cara membuatnya mudah, bisa ikuti panduan ini step by step.

Setelah terbuat section baru, silakan isikan judul dan deskripsi. Kemudian klik tombol $(+)$ untuk membuat form pengisian token

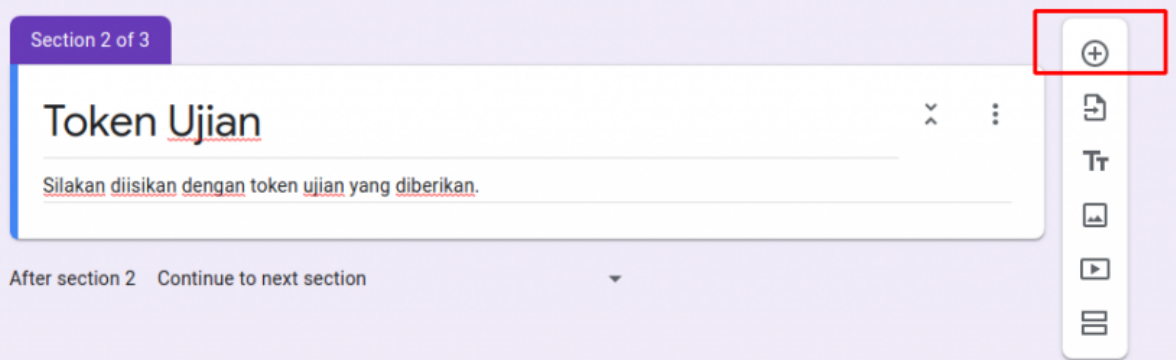

Token bisa Anda sesuaikan dengan yang Anda inginkan bisa dengan huruf acak agar tidak mudah di tebak sebagai kode aksesnya. Silakan buat token dengan response validation.

\section{Section 2 of 4}

\section{Token Ujian}

Silakan diisikan dengan token ujian yang diberikan.

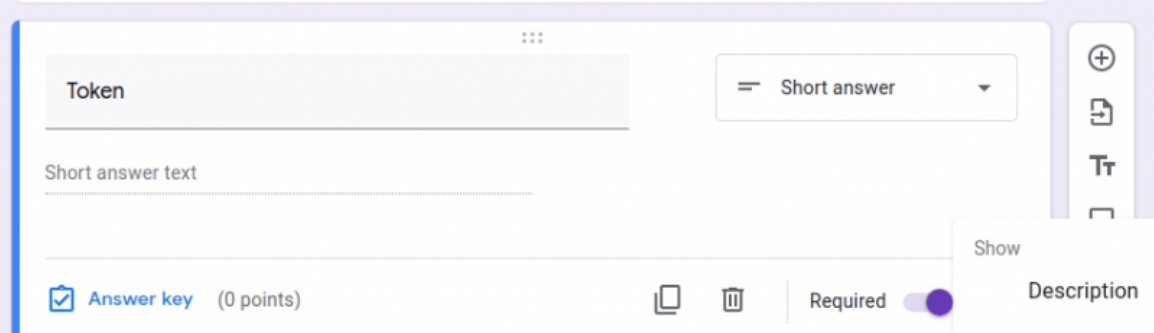

After section 2 Continue to next section

Nantinya akan muncul seperti ini , silakan bisa iisikan seperti ini : 


\section{Section 2 of 2}

\section{Token Ujian}

Silakan diisikan dengan token ujian yang diberikan

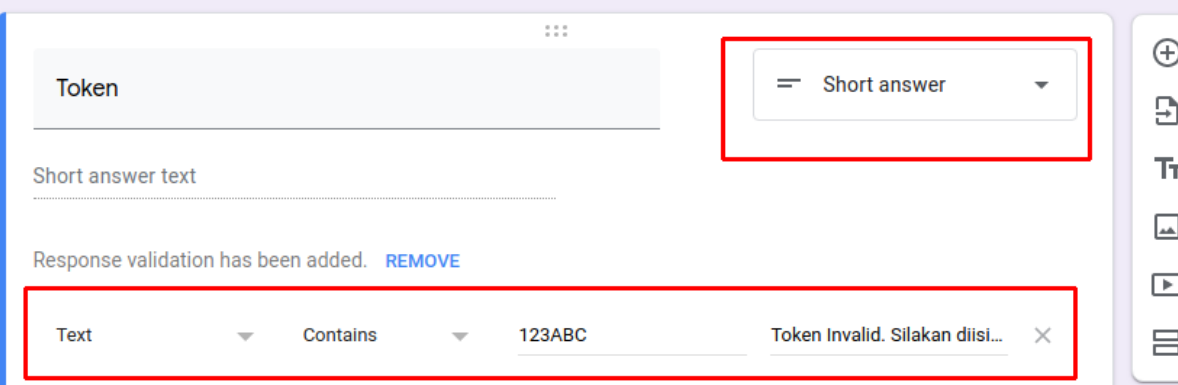

Answer key (0 points)

Required

Description

Response validation

Pada resend validation, saya isiikan type "text" kemudian yang pada bagian textnya itu kode token, Anda bisa isikan acak sesuai keinginan. Pada kolom "custome error text" itu pop up yang akan muncul jika kode yang dimasukkan salah.

Dan selesai, token sudah selesai dibuat.

\section{2 . 2 . 3 . MEMBUAT SOAL}

Untuk selanjutnya, akan pada intinya yakni membuat soal. Sebelum itu, silakan pisahkan dengan section baru lagi dengan cara klik "add section".

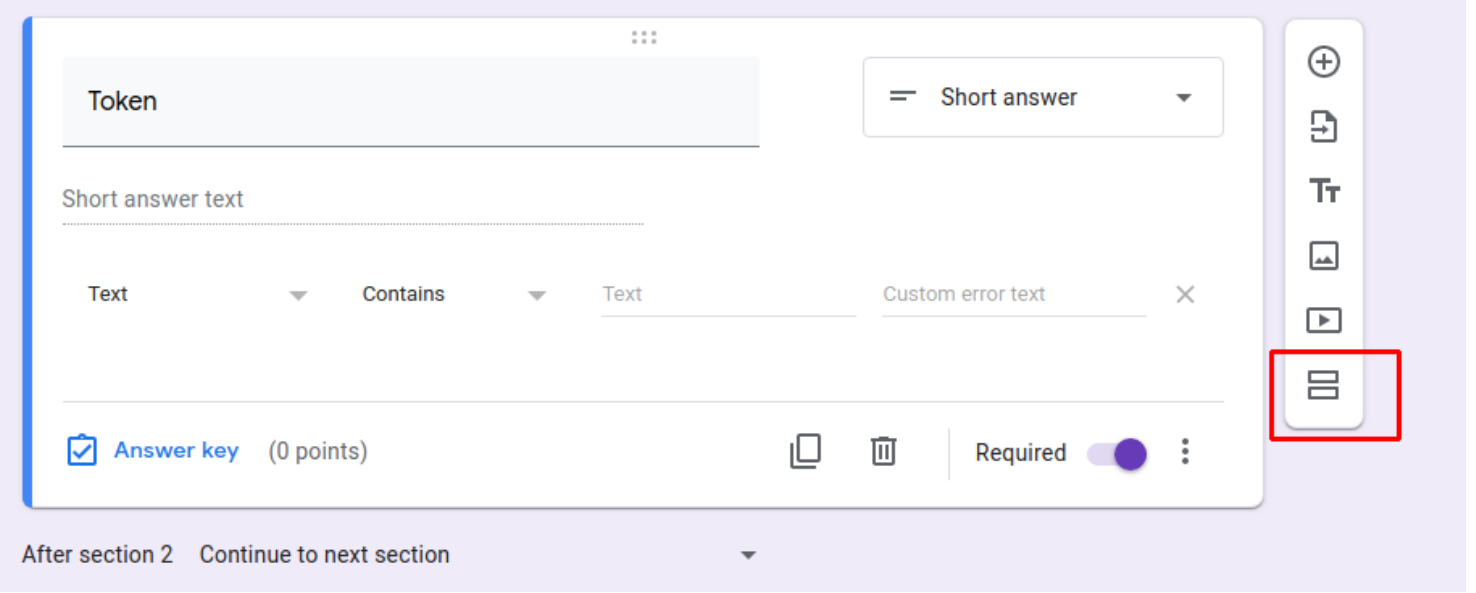

\section{4. MATERIAL}

Fitur selanjutnya yang bisa digunakan yakni "material". Fitur ini cocok digunakan untuk shared materi dalam bentuk file seperti doc, pdf, excell dan lainnya sesuai kebutuhan. Untuk membuatnya, bisa klik create $>$ material : 
Stream Classwork People Grades

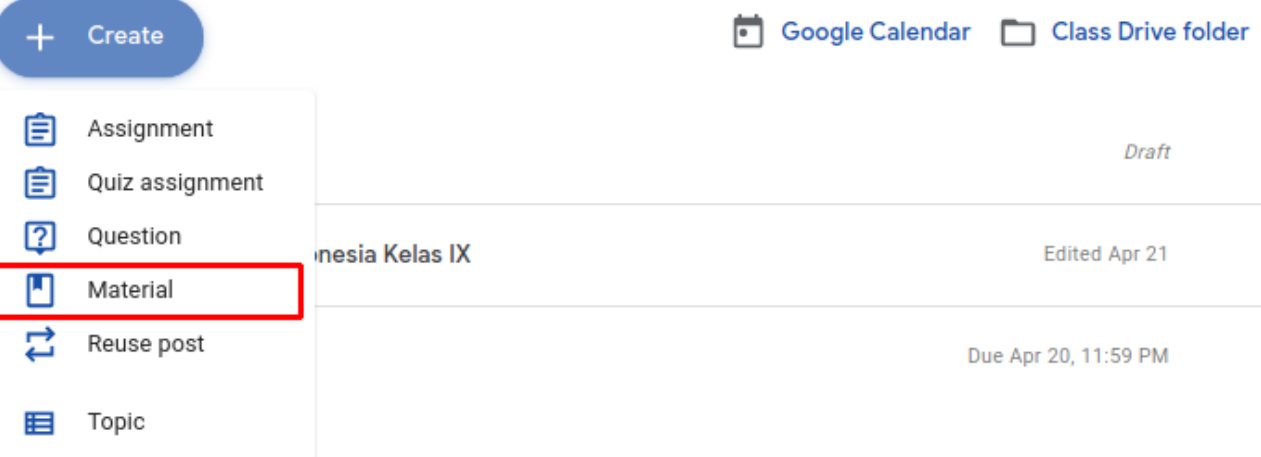

Pada formnya, bisa diisikan dengan keterangan tambahan mengenai materi yang akan diberikan. Seperti fitur fitur lain, pada fitur ini juga bisa di add attachement berupa pdf, docs bahkan hingga link youtube.

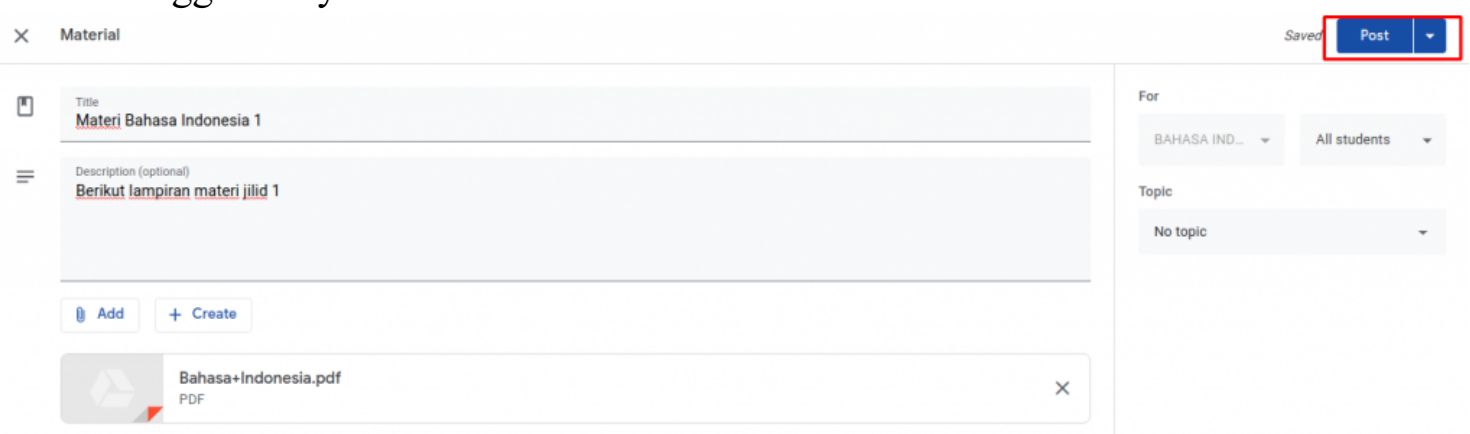

\section{2 . 5 . REUSE}

Fitur terakhir dari google classroom ini adalah reuse, dimana Anda bisa melakukan post ulang assignment lama yang pernah diberikan ke siswa. Berikut langkahnya :

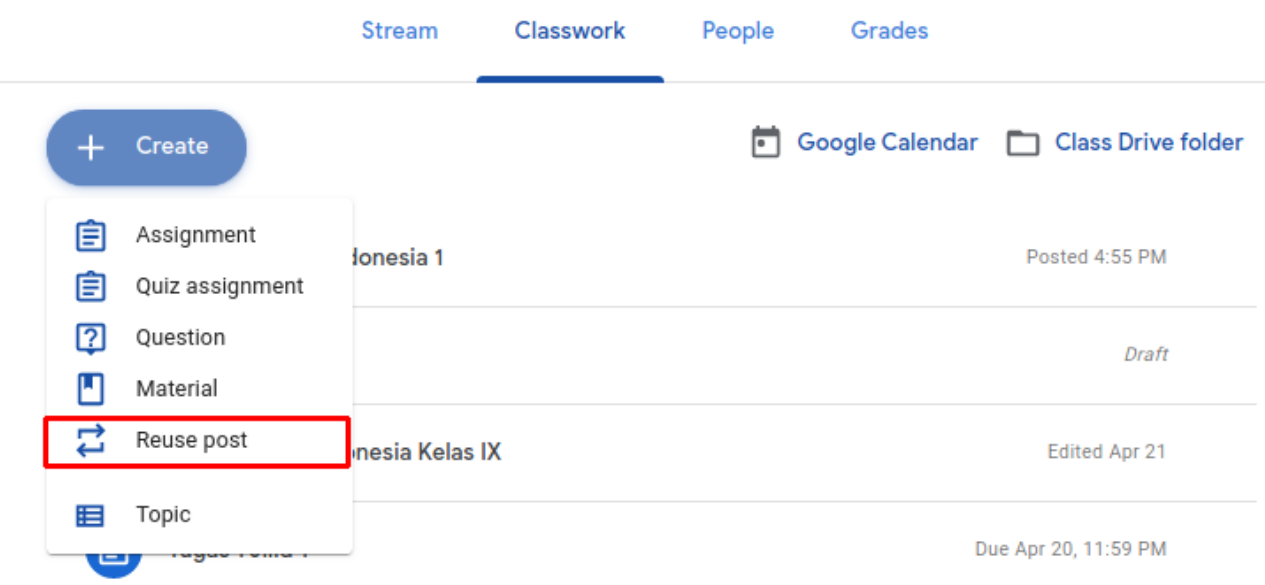

Kemudian Anda tinggal pilih post mana yang akan di re-upload : 


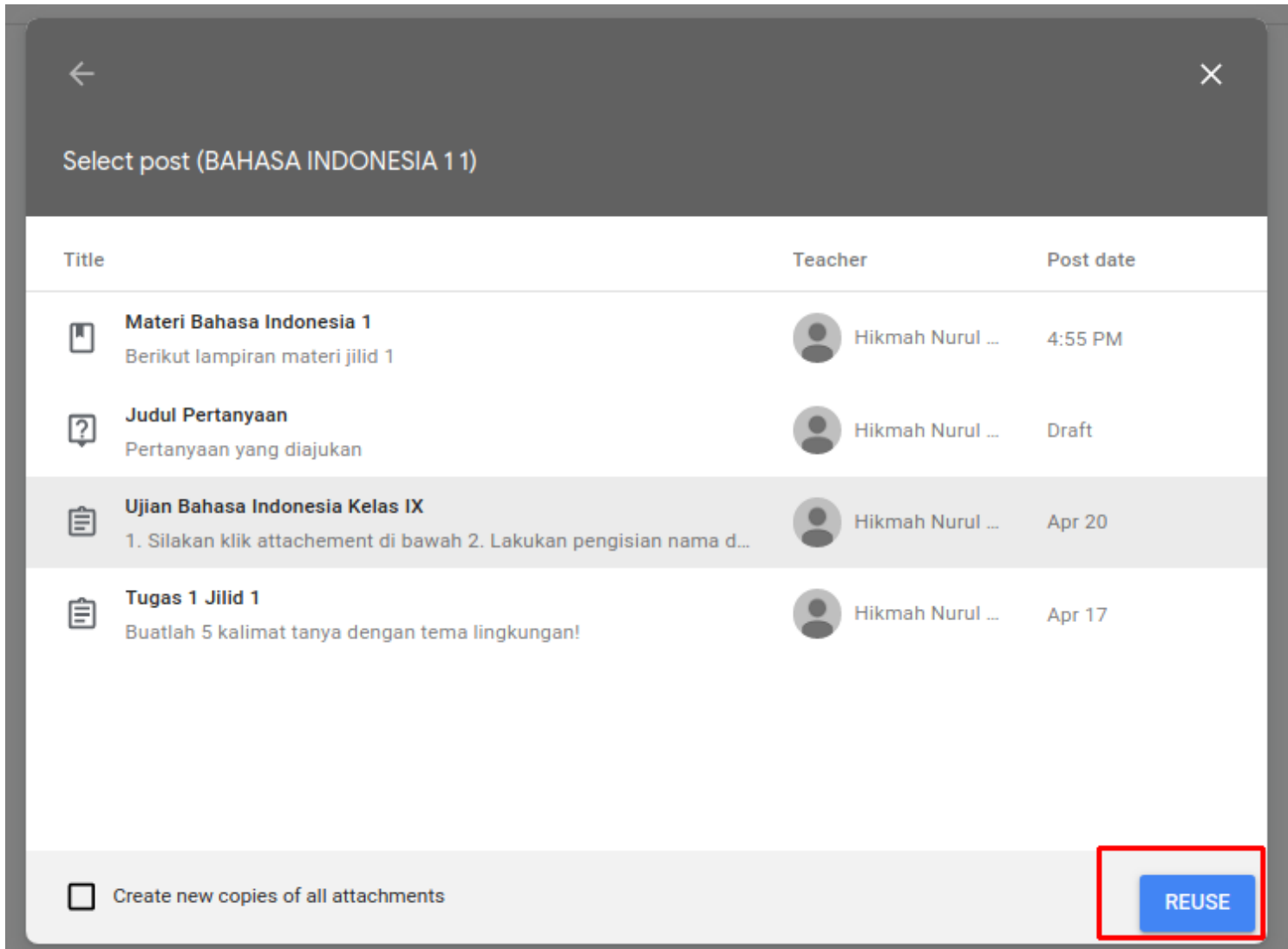

\section{KESIMPULAN}

Kegiatan bimbingan teknis pembelajaran daring mendorong guru untuk kreatif dalam melaksanakan pembelajaran daring selama pandemi. Dengan Google class room guru terbantu dalam direktori data, materi dan soal-soal test sehingga memudahkan pembelajaran daring. Beberapa fator pendukung proses pembelajaran Google Classroom yang perlu ditingkatkan mulai dari kesiapan pengajar yang mampu memberikan instruksi pembelajaran e-learning dengan baik. Memfasilitasi konsultasi untuk menggunakan Google Classroom supaya maksimal serta memotivasi pembelajaran Google Classroom agar semakin aktif.

\section{Ucapan terimakasih}

Penulis mengucapkan terima kasih kepada Universitas Widya Gama Mahakam Samarinda melalui LPPM yang telah memberi bantuan dana untuk kegiatan pengabdian masyarakat sehingga berjalan dengan lancar.

\section{DAFTAR PUSTAKA}

Surat Edaran Nomor 4 Tahun 2020 tentang Pelaksanaan Kebijaksanaan Pendidikan dalam masa Darurat Penyebaran Corona Virus Disease ( COVID-19)

Hikmah Nurul Ardhaningtyas. 2020. Pemanfaatan Google Class Room Sebagai Media Penugasan serta Ujian Online dan Elearning. CV. Rumah Web Indonesia. 
https://www.rumahweb.com/journal/pemanfaatan-google-class-room-sebagai-mediapenugasan-serta-ujian-online-dan-elearning/ Diakses tanggal 22 Desember 2020.

\section{Profil Penulis:}

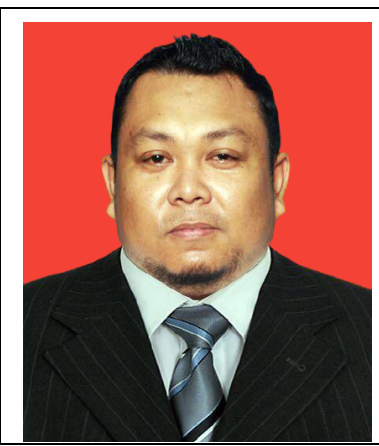

Nur Agus Salim, merupakan staf pengajar di Universitas Widya Gama Mahakam Samarinda pada program studi Pendidikan Guru Sekolah Dasar dengan bidang keahlian Manajemen Pendidikan. Penelitian penulis lebih fokus pada bidang Manajemen Pendidikan dan ke-PGSD-an. Peneliti juga saat ini sebagai Asesor BAN-SM Prov Kalimantan Timur dan pengelola beberapa jurnal nasional. Email: nuragussalim@uwgm.ac.id 